\title{
The Effect of Coarse Aggregates Types on Properties of Self Compacting Concrete
}

\author{
Manar A. Abdul Hady ${ }^{1}$, Ahmed Abd El-azim A. ${ }^{2}$, Hany A. El-Ghazaly ${ }^{3}$ \\ ${ }^{1}$ (Post Graduate Student - Faculty of Engineering - Fayoum University, Egypt) \\ ${ }^{2}$ (Assistant Professor - Faculty of Engineering - Fayoum University, Egypt) \\ ${ }^{3}$ (Professor - Faculty of Engineering - Fayoum University, Egypt
}

\begin{abstract}
The main purpose of this study is to investigate the effect of using three types of coarse aggregates (gravel, basalt and dolomite) and three different percentages of water and cement on the properties of selfcompacting concrete. To this end, nine mixes containing different percentages of water and cement were designed. Three types of aggregates were used namely; gravel, basalt, and dolomite. The all fresh concrete mixes were prepared to achieve standard workability (slump flow). The compression, splitting tensile, and flexural strength tests were carried out on hardened self-compacting concretes after 28 days. In the nine mixes, three types of aggregates (gravel, basalt and dolomite), three cement content (350,400, and $\left.450 \mathrm{~kg} / \mathrm{m}^{3}\right)$, and three water cement ratio $(0.46,0.42$, and 0.38) were used. Results showed that. Slump flow of dolomite selfcompacting concrete is greater than all concrete mixes with gravel and basalt. The density of self-compacting concrete basalt mix is greater than other concrete mixes with gravel and dolomite. The compressive, split tensile, and flexural strengths of self-compacting concrete dolomite mix is higher than all concrete mixes with gravel and basalt.
\end{abstract}

Keywords: self-compacting concrete - fresh - hardened -gravel-basalt-dolomite

\section{Introduction}

Self-Compacting Concrete is a material which under its own self-weight flows to form and fill any shape, attains full compaction, without external energy input, to create a dense homogenous mass [1]. Selfcompacting concrete is an innovative concrete that does not require vibration for placing and compaction. Selfcompacting concrete is completely filling formwork and achieving full compaction, even in the presence of congested reinforcement [2]. The characteristic differences between a conventional concrete and an SCC mix design is illustrated by Schutter and others [3]. Effect of mineral admixtures on the correlation between ultrasonic velocity and compressive strength for self-compacting concrete is studied by Ulucan and others [4]. Properties of fresh and hardened recycled aggregate self compacting concrete studied by Revathi and others [5]. The behavior of self-compacting concrete bond strength using pull-out, restrained shrinkage cracking of selfcompacting concrete, and the behavior of self-compacting concrete shrinkage are investigated by Filho [6], Loser [7], and Aslani [8]. The effect of different mineral admixtures on the performance of self-compacting concrete and The effect of high range water reducing superplasticizer in self compacting concrete are studied by Ramanathan [9] and Dubey [10].

\section{Materials Used}

In this experimental study cement, sand, and coarse aggregates (gravel, basalt and dolomite) were used. Table (1) and table (2) show properties of sand, gravel, basalt and dolomite used. Limestones are sedimentary rocks primarily of calcium carbonate. Filler is a very finely-ground material, of about the same fineness as Portland cement is used in concrete with $30 \%$ by weight of cement. Sika ViscoCrete_3425 is a third generation superplasticizer for homogenous concrete and mortar. Table (3) show the characteristics of (ViscoCrete_3425). For self compaction concrete $1.5 \%$ liter by weight of cement is used.

Table (1): Physical Properties of the Sand

\begin{tabular}{|c|c|c|}
\hline Properties & Measured Values & Specification Limits \\
\hline Specific Gravity & 2.5 & $2.5-2.7$ \\
\hline Volume Weight (t)m3) & 1.55 & $1.4-1.7$ \\
\hline Fineness Modulus & 2.57 & $2-2.73$ \\
\hline Percentage Of Dust And Fine Material (By Weight) & $1.6 \%$ & $<3 \%$ by weight \\
\hline
\end{tabular}


Table (2): Characteristics of Coarse Aggregate

\begin{tabular}{|c|c|c|c|}
\hline Properties & \multicolumn{3}{|c|}{ Measured Values } \\
\cline { 2 - 4 } & Gravel & Basalt & Dolomite \\
\hline Specific Gravity & 2.55 & 2.63 & 2.6 \\
\hline Volume Weight (t)m3) & 1.68 & 1.61 & 1.56 \\
\hline \% Absorption & $\mathbf{0 . 4 \%}$ & $\mathbf{0 . 9 \%}$ & $1.6 \%$ \\
\hline
\end{tabular}

Table (3): The Characteristics of (ViscoCrete_3425)

\begin{tabular}{|c|c|c|c|c|}
\hline Base & Color & Density & pH Value & Solid Content \\
\hline Aqueous solution of modified polycarboxylates & Clear Liquid & $1.08 \mathrm{~kg} /$ lit & $\mathbf{4 . 0}$ & $\mathbf{4 0 \%}$ by weight \\
\hline
\end{tabular}

\section{Mix Proportions}

The mix design and testing program were conducted in accordance with Egyptian code and ASTM standards. Nine mixes containing different types of coarse aggregates and different percentages of water and cement were designed as shown in Table (4). In Group (1), the cement content was $350 \mathrm{~kg} / \mathrm{m}^{3}$ and $(\mathrm{W} / \mathrm{C})=0.46$. While, in Group (2), the cement content was $400 \mathrm{~kg} / \mathrm{m}^{3}$ and (W/C) $=0.0 .42$, and Group (3), the cement content was $450 \mathrm{~kg} / \mathrm{m}^{3}$ and $(\mathrm{W} / \mathrm{C})=0.38$. For each mix 6 cubes $(150 \times 150 \mathrm{~mm}), 3$ Cylinders $(150 \times 300 \mathrm{~mm})$, and 3 beams $(100 \times 100 \times 500 \mathrm{~mm})$ were prepared. Concrete samples were cured in water until testing.

Table (4): Concrete Mixes

\begin{tabular}{|c|c|c|c|c|c|c|c|c|c|}
\hline $\begin{array}{l}\text { Mix } \\
\text { No. }\end{array}$ & & $\begin{array}{l}\text { roup } \\
\text { No. }\end{array}$ & $\begin{array}{c}\text { Water } \\
\left(\mathrm{kg} / \mathrm{m}^{3}\right)\end{array}$ & $\begin{array}{l}\text { Cement } \\
\left(\mathrm{kg} / \mathrm{m}^{3}\right)\end{array}$ & $\begin{array}{c}\text { Sand } \\
\left(\mathrm{kg} / \mathrm{m}^{3}\right)\end{array}$ & $\begin{array}{c}\text { Aggregate } \\
\left(\mathrm{kg} / \mathrm{m}^{3}\right)\end{array}$ & $\begin{array}{l}\text { Lime stone } \\
\text { powder }\end{array}$ & $\begin{array}{l}\text { Superplasticizer } \\
\text { (Viscocrete342) }\end{array}$ & $\begin{array}{c}\text { Type of coarse } \\
\text { Aggregates }\end{array}$ \\
\hline \multirow{3}{*}{ M1 } & 1 & M1-1 & 161 & 350 & 829 & 912 & 105 & 5.25 & \multirow{3}{*}{ Gravel } \\
\hline & 2 & M1-2 & 168 & 400 & 796 & 875 & 120 & 6.00 & \\
\hline & 3 & M1-3 & 171 & 450 & 766 & 843 & 135 & 6.75 & \\
\hline \multirow{3}{*}{ M2 } & 1 & M2-1 & 161 & 350 & 843 & 927 & 105 & 5.25 & \multirow{3}{*}{ Basalt } \\
\hline & 2 & M2-2 & 168 & 400 & 808 & 889 & 120 & 6.00 & \\
\hline & 3 & M2-3 & 171 & 450 & 779 & 856 & 135 & 6.75 & \\
\hline \multirow{3}{*}{ M3 } & 1 & M3-1 & 161 & 350 & 838 & 922 & 105 & 5.25 & \multirow{3}{*}{ Dolomite } \\
\hline & 2 & M3-2 & 168 & 400 & 804 & 884 & 120 & 6.00 & \\
\hline & 3 & M3-3 & 171 & 450 & 777 & 851 & 135 & 6.75 & \\
\hline
\end{tabular}

\section{Test Program}

The slump test is used to measure the consistency of fresh concrete. It was carried out according to ASTM C143. The compressive and splitting tensile strengths of concrete were determined using compression testing machine having $2000 \mathrm{KN}$ capacity. The loading rates applied in the compressive and splitting tensile tests were 0.6 and $0.03 \mathrm{~N} / \mathrm{mm}^{2} / \mathrm{sec}$ respectively. The compressive strength was measured by using cubes $(150 \times 150 \mathrm{~mm})$ at the ages of 7 , and 28 days while the tensile splitting strength was only measured by using cylinder $(150 \times 300 \mathrm{~mm})$ at 28 days. For the flexural strength of hardened concrete, beam specimens of size 100x100x500 mm were used. The specimens were placed in UTM and tested for flexural strength. The loading rates applied was $0.06 \mathrm{~N} / \mathrm{mm}^{2} / \mathrm{sec}$, as shown in figure (1). The average results of three samples were calculated for all tests.

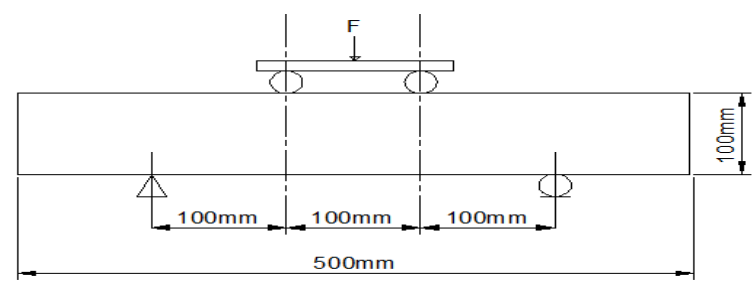

Fig.(1): Flexural Strength Test

V. Results And Discussion

Results of slump test, density, compressive strength, splitting tensile strength, and flexural strength for the nine mixes of concrete were calculated in table (5). 
Table (5): Results of Slump, Compressive Strength, Split Tensile Strength and Flexural Strength Tests for Recycled Coarse Aggregates Concrete

\begin{tabular}{|c|c|c|c|c|c|c|c|c|c|}
\hline $\begin{array}{c}\text { Mix } \\
\text { No. }\end{array}$ & & $\begin{array}{l}\text { oup } \\
\text { to. }\end{array}$ & $\begin{array}{c}\text { Slump } \\
\text { Flow } \\
\text { Diameter } \\
(\mathbf{m m})\end{array}$ & $\begin{array}{c}\text { Density } \\
\left(t / \mathrm{m}^{3}\right) \\
\end{array}$ & $\begin{array}{c}\text { Compressive } \\
\text { Strength at } 7 \\
\text { days } \\
\left(\mathrm{kg} / \mathrm{cm}^{2}\right)\end{array}$ & $\begin{array}{c}\text { Compressive } \\
\text { Strength at } 28 \\
\text { days } \\
\left(\mathrm{kg} / \mathrm{cm}^{2}\right)\end{array}$ & $\begin{array}{c}\text { Splitting } \\
\text { Tensile } \\
\text { Strength at } 28 \\
\text { days }\left(\mathrm{kg} / \mathrm{cm}^{2}\right)\end{array}$ & $\begin{array}{c}\text { Flexural } \\
\text { Strength at } \\
28 \text { days } \\
\left(\mathrm{kg} / \mathrm{cm}^{2}\right)\end{array}$ & $\begin{array}{c}\text { Type of } \\
\text { coarse } \\
\text { Aggregates }\end{array}$ \\
\hline \multirow{3}{*}{ M1 } & 1 & M1-1 & 60 & 2.346 & 197 & 283 & 25.8 & 52.2 & \multirow{3}{*}{ Gravel } \\
\hline & 2 & M1-2 & 61 & 2.370 & 302 & 426 & 32.2 & 57.5 & \\
\hline & 3 & M1-3 & 65 & 2.415 & 333 & 447 & 33.5 & 61.2 & \\
\hline \multirow{3}{*}{ M2 } & 1 & M2-1 & 62 & 2.454 & 278 & 362 & 31.4 & 58.4 & \multirow{3}{*}{ Basalt } \\
\hline & 2 & M2-2 & 63 & 2.486 & 311 & 450 & 36.2 & 62.6 & \\
\hline & 3 & M2-3 & 70 & 2.442 & 406 & 507 & 38.8 & 77.2 & \\
\hline \multirow{3}{*}{ M3 } & 1 & M3-1 & 63 & 2.370 & 325 & 397 & 36.2 & 59.1 & \multirow{3}{*}{ Dolomite } \\
\hline & 2 & M3-2 & 65 & 2.375 & 352 & 466 & 37.3 & 72.3 & \\
\hline & 3 & M3-3 & 75 & 2.423 & 462 & 575 & 48.2 & 89.2 & \\
\hline
\end{tabular}

\section{A. SLUMP FLOW}

The slump flow shape is shown in figure (2) and the difference between the nine mixes with different water cement (w/c) ratio is shown in Figure (3). It is observed that slump flow diameter for dolomite concrete has the highest values $(63,65$, and $75 \mathrm{~mm})$, gravel concrete has the lowest values $(60,61$, and $65 \mathrm{~mm})$, and basalt concrete has values $(62,63$, and $70 \mathrm{~mm})$.

\section{B. DENSITY}

The density of concrete for the nine mixes with different water cement (w/c) ratio is shown in Figure (4). It is observed that density for gravel concrete has the lowest values $\left(2.346,2.370\right.$, and $2.415 \mathrm{t}^{3}$ ), basalt concrete has the highest values $\left(2.454,2.486\right.$, and $\left.2.442 \mathrm{t}^{3}\right)$, and dolomite concrete has values $(2.370,2.375$, and $2.423 \mathrm{t}^{3} \mathrm{~m}^{3}$.

\section{COMPRESSION STRRENGTH}

The results of compressive strength test at 7 days for the nine mixes with different water cement (w/c) ratio is shown in Figure (5). It is observed that compressive strength at 7 days for gravel concrete has the lowest values $\left(197,302\right.$, and $\left.333 \mathrm{kglcm}^{2}\right)$, dolomite concrete has the highest values $\left(325,352\right.$, and $\left.462 \mathrm{~kg} / \mathrm{cm}^{2}\right)$, and basalt concrete has values $\left(278,311\right.$, and $\left.406 \mathrm{kglcm}^{2}\right)$.

The results of compressive strength test at 28 days for the nine mixes with different water cement $(\mathrm{w} / \mathrm{c})$ ratio is shown in Figure (6). It is observed that compressive strength at 28 days for gravel concrete has the lowest values $\left(283,429\right.$, and $\left.447 \mathrm{kglcm}^{2}\right)$, dolomite concrete has the highest values $\left(397,466\right.$, and $\left.575 \mathrm{~kg} \backslash \mathrm{cm}^{2}\right)$, and basalt concrete has values $\left(362,450\right.$, and $\left.507 \mathrm{kglcm}^{2}\right)$.

Relation between compressive strength at 28 days and compressive strength at 7 days for the nine mixes with different water cement (w/c) ratio is shown in Figure (7). It is observed that:

$f_{\text {cu }}$ at 7 days $\approx 0.7616 f_{\text {cu }}$ at 28 day

Where: $\mathrm{f}_{\mathrm{cu}=}$ compressive strength

\section{SPLITTING TENSILE STRRENGTH}

The results of splitting tensile strength test at 28 days for the nine mixes with different water cement $(w / c)$ ratio is shown in Figure (8). It is observed that splitting tensile strength for gravel concrete has the lowest values $\left(25.8,32.2\right.$, and $33.5 \mathrm{kglcm}$ ), dolomite concrete has the highest values $\left(36.2,37.3\right.$, and $\left.48.2 \mathrm{~kg} \backslash \mathrm{cm}^{2}\right)$, and basalt concrete has values $\left(31.4,36.2\right.$, and $\left.38.8 \mathrm{kglcm}^{2}\right)$. Relation between splitting tensile strength and compressive strength for the nine mixes with different water cement (w/c) ratio is shown in Figure (9). It is observed that:

$\mathbf{f}_{\mathbf{t}} \approx \mathbf{0 . 0 8 1 3} \mathbf{f}_{\text {cu }}$

Where: $f_{t}=$ splitting tensile strength.

\section{E. FLEXURAL STRRENGTH}

The results of flexural strength test at 28 days for the nine mixes with different water cement (w/c) ratio is shown in Figure (10). It is observed that flexural strength for gravel concrete has the lowest values (52.2, 57.5 , and $61.2 \mathrm{~kg} \mathrm{~cm}^{2}$ ), dolomite concrete has the highest values $\left(59.1,72.3\right.$, and $89.2 \mathrm{~kg} \backslash \mathrm{cm}^{2}$ ), and basalt concrete has values $\left(58.4,62.6\right.$, and $\left.77.2 \mathrm{kglcm}^{2}\right)$. Relation between flexural strength and compressive strength for the nine mixes with different water cement (w/c) ratio is shown in Figure (11). It is observed that:

$$
\mathbf{f}_{\mathbf{f}} \approx \mathbf{0 . 1 5 0 0} \mathbf{f}_{\text {cu }}
$$

Where: $\mathrm{f}_{\mathrm{f}}=$ flexural strength 


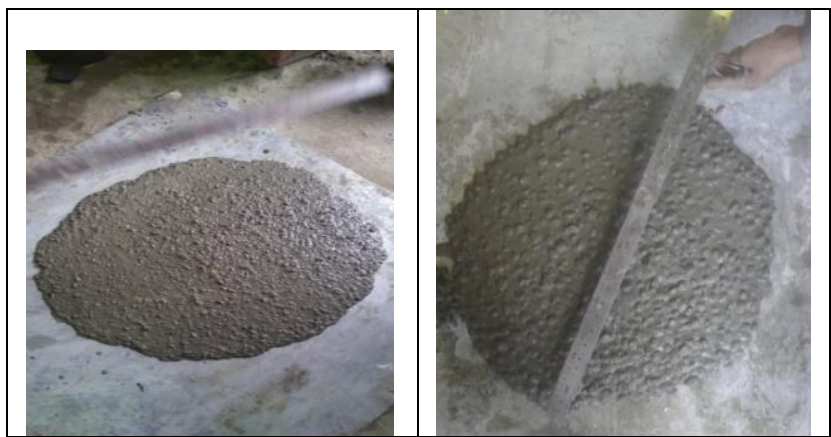

Fig.(2): Concrete Slump Flow Test

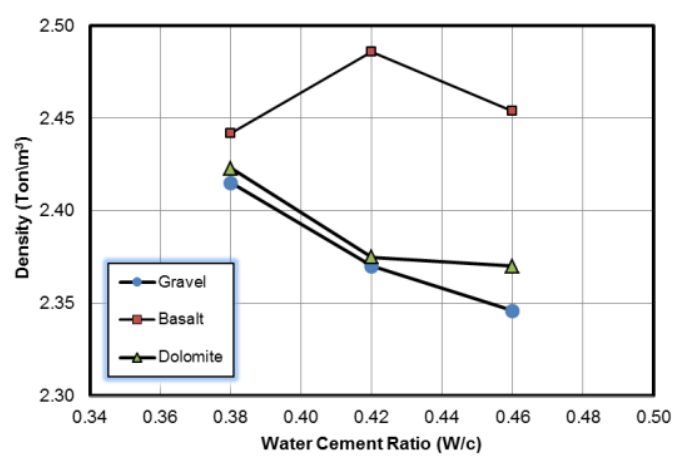

Fig.(4): Relation between Water cement ratio and Density of Concrete for Different Types Aggregates

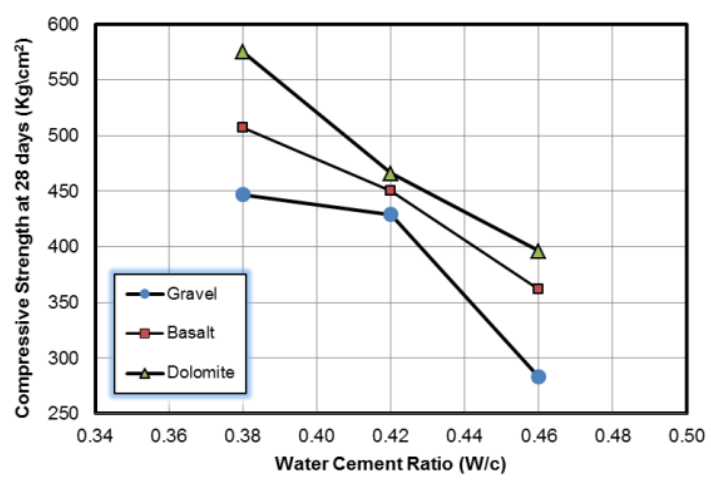

Fig.(6): Relation between Water cement ratio and Compressive Strenghth at 28 days for Different Type Aggregates

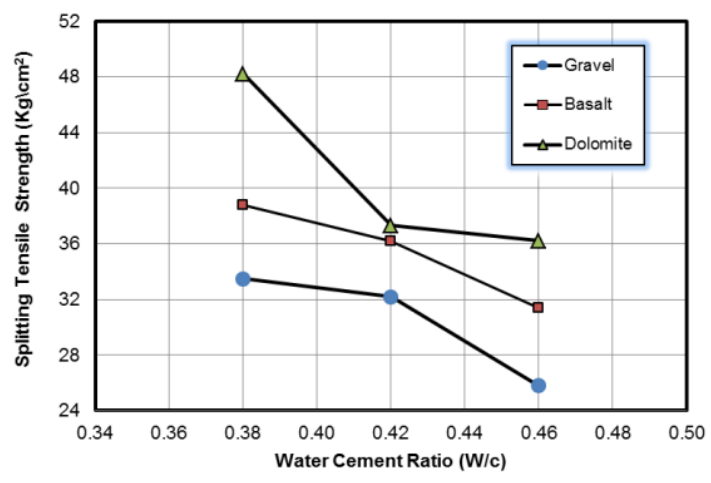

Fig.(8): Relation between Water cement ratio and Splitting Tensile Strenghth for Different Types Aggregates

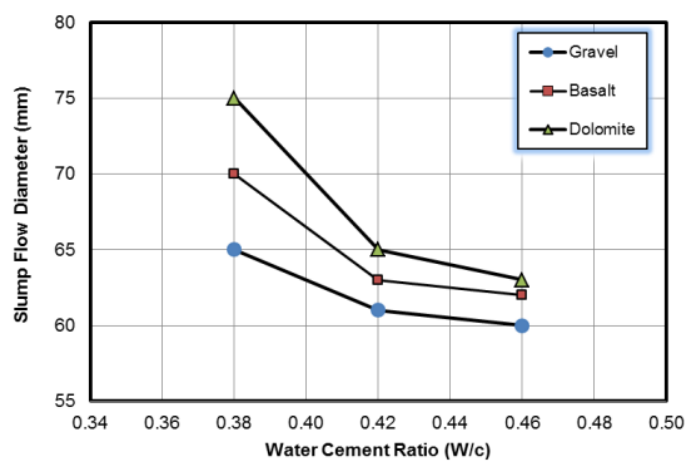

Fig.(3): Relation between Water cement ratio and Slump flow Diameter for Different Types Aggregates

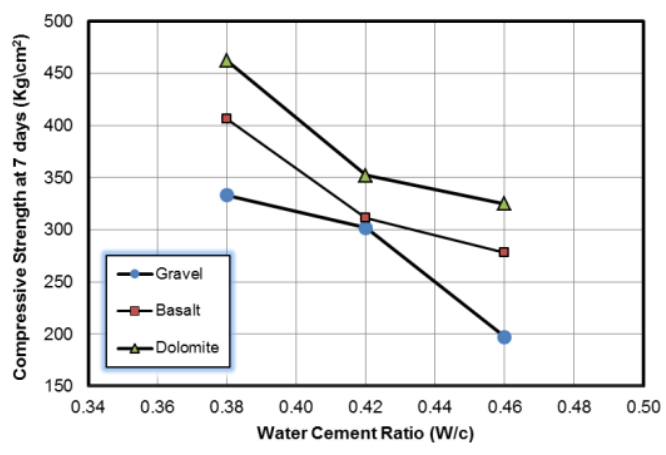

Fig.(5): Relation between Water cement ratio and Compressive Strenghth at 7 days for Different Types Aggregates

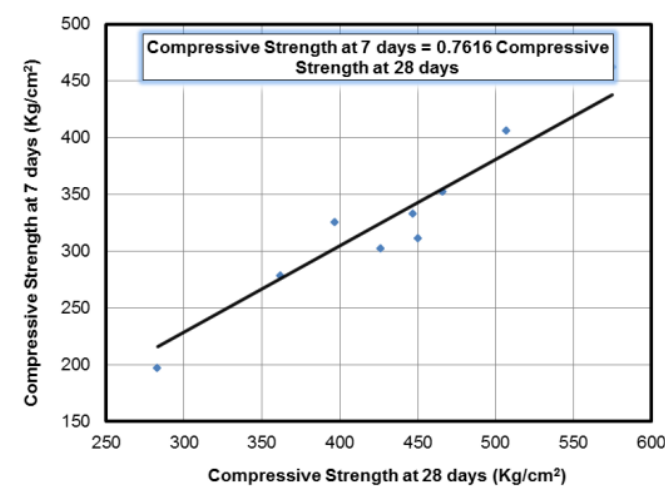

Fig.(7): Relation between Compressive Strength at 7 days and 28 days for slef Compacting Concrete

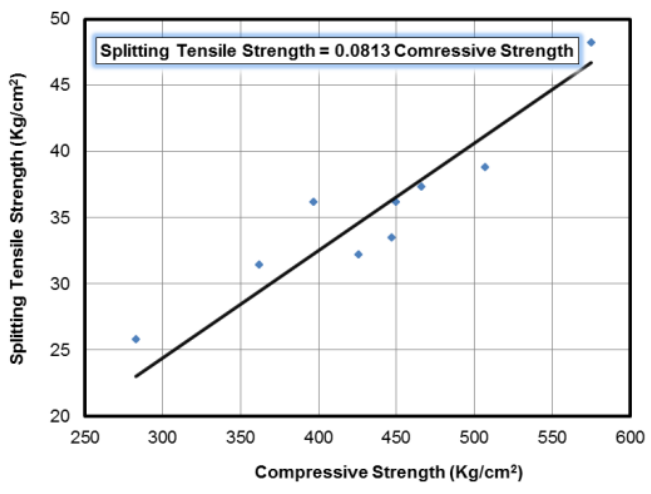

Fig.(9): Relation between Compressive Strength and Splitting Tensile Strength for Slef Compacting Concrete 


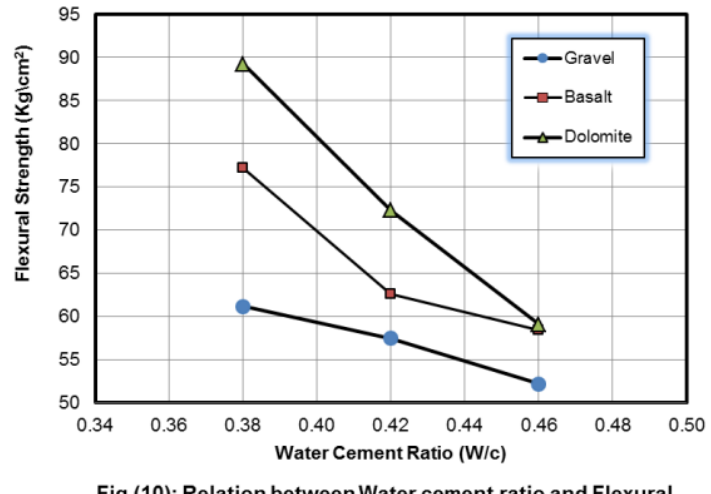

Fig.(10): Relation between Water cement ratio and Flexura Strenghth for Different Types Aggregates

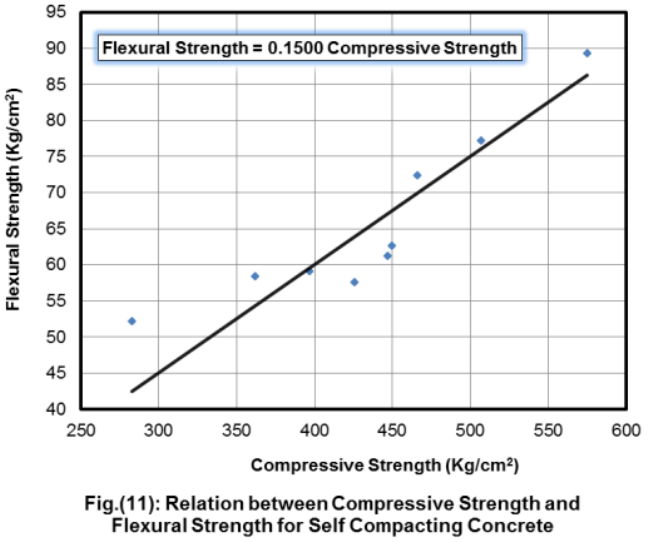

VI. Conclusion

The main conclusions due to the experimental results presented in this paper are as the follows:

1. Slump flow of dolomite self-compacting concrete is greater than gravel and basalt self_compacting concrete for all mixes. As a result of increasing water cement ratio in the mix due to increase the absorption of dolomite. The value of slump flow is increased due to increase the content of cement.

2. Density of basalt self-compacting concrete is greater than all mixes with gravel and dolomite.

3. Compressive strength for self-compacting concrete dolomite mix at 7 days is higher than all selfcompacting concrete mixes (gravel and basalt) by average $27 \%$ and $13 \%$.

4. Compressive strength for self-compacting concrete dolomite mix at 28 days is higher than all selfcompacting concrete mixes (gravel and basalt) by average 19\% and $8 \%$.

5. Compressive Strength at 7 days $\approx 0.7616$ Compressive Strength at 28 days

6. Splitting tensile strength for self-compacting concrete dolomite mix is higher than all self-compacting concrete mixes (gravel and basalt) by average $25 \%$ and $13 \%$.

7. Splitting Tensile Strength $\approx 0.0813$ Compressive Strength

8. Flexural strength for self-compacting concrete dolomite mix is higher than all self-compacting concrete mixes (gravel and basalt) by average $23 \%$ and $10 \%$.

9. Flexural Strength $\approx 0.1500$ Compressive Strength

10. Dolomite is the best type of aggregate to use in self-compacting concrete.

\section{References}

[1]. Holton,I., The Effects of SCC on The Construction Process, Department of Trade and Industry and Building Research Establishment, Watford, UK, 2003

[2]. European Concrete Platform, The European Guibelines for Self-Compacting Concrete, 2012.

[3]. Schutter, D., Bartos, G., Domone, P., and Gibbs, J., Self-Compacting Concrete, Whittles Publishing, Dunbeath, UK, 2008.

[4]. Ulucan, Z.C., Türk, K., and Karatas, M., Effect of Mineral Admixtures on the Correlation between Ultrasonic Velocity and Compressive Strength for Self-Compacting Concrete, Department of Civil Engineering, Faculty of Engineering, Fírat University, Russian Journal of Nondestructive Testing, Elazi, Turkey, vol. 44, No. 5, 2008, pp. 367-374.

[5]. Revathi,P., Selvi, R., and Velin, S.S., Investigations on Fresh and Hardened Properties of Recycled Aggregate Self Compacting Concrete, Journal. Institute. Engineering, India,2014, pp.179-185.

[6]. Filho, F., El Debs, M., and El Debs, A., Bond-slip behavior of self-compacting concrete and vibrated concrete using pull-out and beam tests, Materials and Structures, vol.41, 2008, pp.1073-1089.

[7]. Loser, R., and Leemann, R., Shrinkage and restrained shrinkage cracking of self-compacting concrete compared to conventionally vibrated concrete, Materials and Structures, vol.42, 2009, pp.71-82.

[8]. Aslani, F., and Nejadi, S., Shrinkage Behavior of Self-Compacting Concrete, Journal of Zhejiang University-SCIENCE A (Applied Physics \& Engineering), Australia, vol.13, No.6, 2012, pp.407-419

[9]. Ramanathan, P., Baskar, I., Muthupriya, P., and Venkatasubramani, K., Performance of Self-Compacting Concrete Containing Different Mineral Admixtures, KSCE Journal of Civil Engineering, vol.17, No.2, 2013, pp.465-472.

[10]. Dubey, R., and Kumar,P., An Experimental Study for Optimization of High Tange Water Reducing Superplasticizer in Self Compacting Concrete, Department of Civil Engineering, National Institute of Technology,Journal of structural engineering, Hamirpur 177005, India, vol.7, No.1, 2013, pp.62-71. 